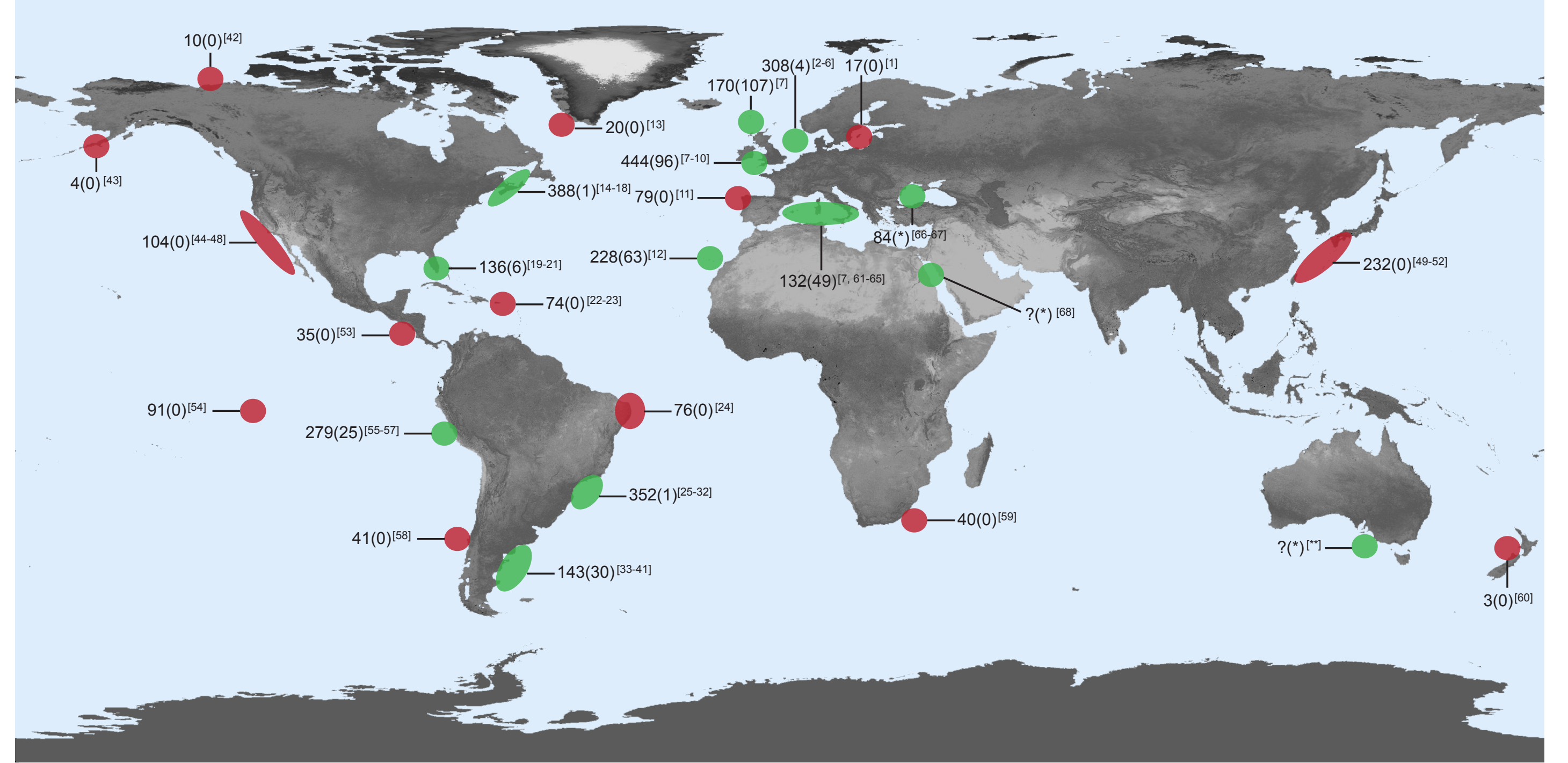

S1 Fig. Worldwide distribution of Pholeter gastrophilus. Geographically distributed surveyed localities for $P$. gastrophilus. The number outside parentheses is the amount of individual cetacean species surveyed for $P$. gastrophilus; the number in parentheses is the number of infected dolphins; and the number in square brackets indicates the bibliographic source. Complete references are included.

Boreal Atlantic
Baltic Sea $=[1]$
North Sea $=[2-6]$
Feroe Islands = [7]
United Kingdom and Ireland =
Galicia (Spain) = [11]
Canary Islands (Spain) = [12]
West Greenland = [13]
North West Atlantic = [14-18]

Tropical Atlantic

Florida $=[19-21]$

Puerto Rico and Virgin Islands = [22-23]

Northeastern Brazil $=[24]$

Southern Brazil $=[25-32]$

\section{Austral Atlantic}

Patagonia (Argentina) $=[33-41]$

Boreal Pacific

Canada $=[42]$

Alaska $($ USA $)=[43]$

Oregon and California (USA) $=[44-48]$

Hong Kong (China) and Japan = [49-52]
Tropical Pacific

Costa Rica $=[53]$

Eastern Tropical Pacific $=[54]$

Peru $=[55-57]$

Austral Pacific

Chile $=[58]$

South Africa $=[59]$

New Zealand $=[60]$

Mediterranean and Black Sea

Mediterranean Sea $=[7,61-65]$

Black Sea $=[66-67]$

\section{Red Sea \\ Egypt $=[68]$}

? Information on the number of sampled hosts is missing

$\left.{ }^{*}\right)$ Information on the number of infected hosts is missing; only presence of $P$. gastrophilus is reported.

${ }^{* * *}$ Personal communication from Ms. Jo Wood and Leslie Chisholm (Parasitology Collection Manager, South Australian Museum). 


\section{REFERENCES}

[1] Rokicki J, Berland B, Wróblewski J. Helminths of the harbour porpoise, Phocoena phocoena (L.), in the southern Baltic. Acta Parasitol. 1997; 42: 36-39.

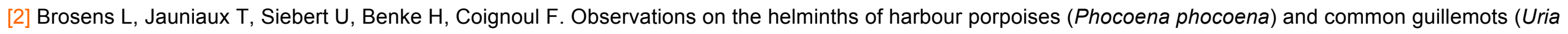
algae) from the Belgian and German coasts. Vet. Rec. 1996; 139: 254-257.

[3] Clausen B, Andersen S. Health status of harbour porpoise (Phocoena phocoena) from Danish waters. Dan. Rev. Game Biol. 1988; $13:$ 1-20.

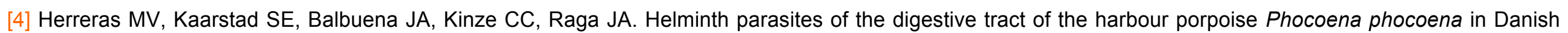
waters: a comparative geographical analysis. Dis. Aquat. Org. 1997; 28: 163-167.

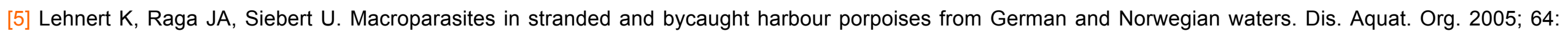
265-269.

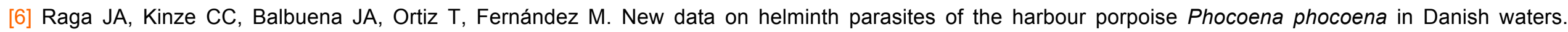
Proceedings of the 3rd Annual Conference of the European Cetacean Society, La Rochelle, France, 24-26 Februrary; 1989. pp. 88-90.

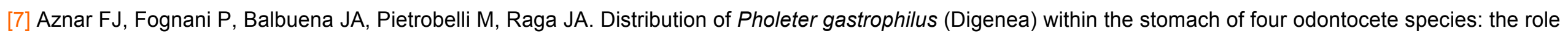
of the diet and digestive physiology of hosts. Parasitology. 2006; 133: 369-380.

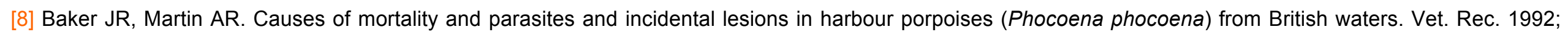
130: 554-558.

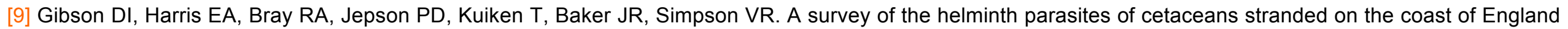
and Wales during the period 1990-1994. J. Zool. 1998; 244: 563-574.

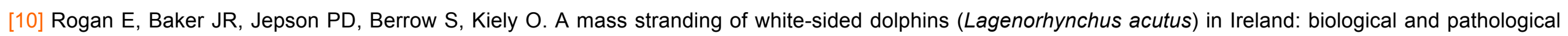
studies. J. Zool. 1997; 242: 217-227.

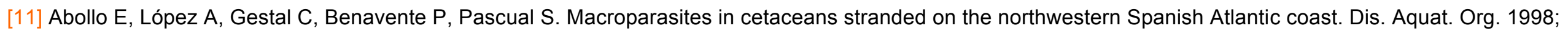
32: 227-231. 


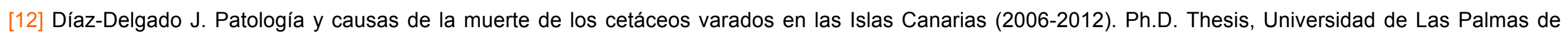
Gran Canaria. 2015. Available from: http://hdl.handle.net/10553/17258.

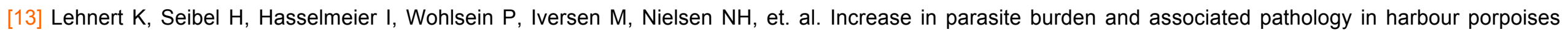
(Phocoena phocoena) in West Greenland. Polar Biol. 2014; 37: 321-331.

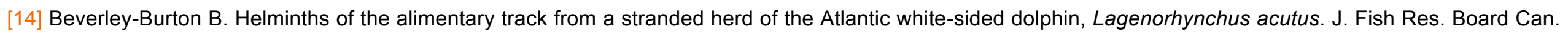
1978; 35: 1356-1359.

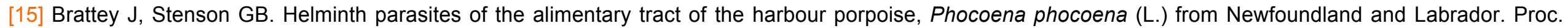
Helminthol. Soc. Wash. 1995; 62, 209-216.

[16] Cowan DF. Helminth parasites of the pilot whale Globicephala melaena (Traill 1809). J. Parasitol. 1967; 53: $166-167$.

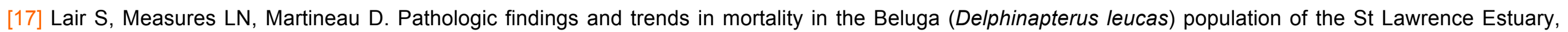
Quebec, Canada, from 1983 to 2012. Vet. Pathol. 2015; 53: 22-36.

[18] Measures LN, Béland P, Martineau D, De Guise S. Helminths of an endangered population of belugas, Delphinapterus leucas, in the St. Lawrence estuary, Canada. Can. J. Zool. 1995; 73: 1402-1409.

[19] Forrester DJ, Robertson WD. Helminths of rough-toothed dolphins, Steno bredanensis Lesson 1828, from Florida waters. J. Parasitol. $1975 ; 61,922$.

[20] Woodard JC, Zam SG, Caldwell DK, Caldwell MC. Some parasitic diseases of dolphins. Vet. Pathol. 1969; 6: 257-272.

[21] Zam SG, Caldwell DK, Caldwell MC. Some endoparasites from small odontocete cetaceans collected in Florida and Georgia. Cetology. $1971 ; 2: 1-11$.

[22] Colón-Llavina MM, Mignucci-Giannoni A, Mattiucci S, Paoletti M, Nascetti G, Williams EH. Additional records of metazoan parasites from Caribbean marine mammals, including genetically identified anisakid nematodes. Parasitol. Res. 2009; 105: 1239-1252.

[23] Mignucci-Giannoni A, Hoberg EP, Siegel-Causey D, Williams EH. Metazoan parasites and other symbionts of cetaceans in the Caribbean. J. Parasitol. 1998; 84: 939-946. 


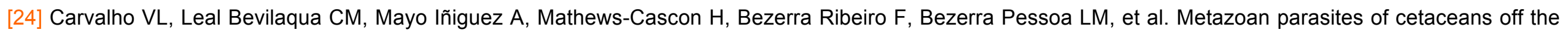
northeastern coast of Brazil. Vet. Parasitol. 2010; 173: 116-122.

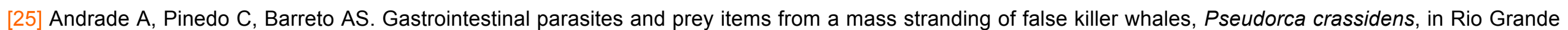
do Sul, Southern Brazil. Rev. Bras. Biol. 2001; 61: 55-61.

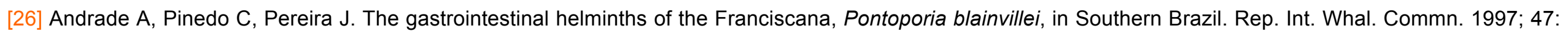
669-673.

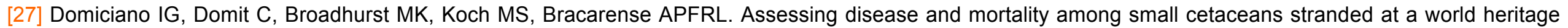
site in Southern Brazil. PLoS One. 2016; 11(2): e0149295.

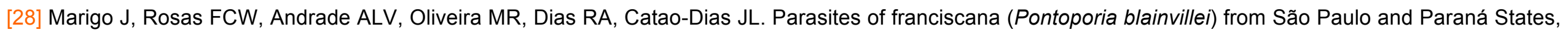
Brazil. LAJAM. 2002; 1: 115-122.

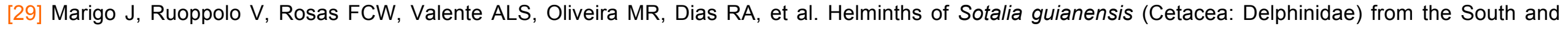
Southeastern Coasts of Brazil. J. Wildl. Dis. 2010; 46: 599-602.

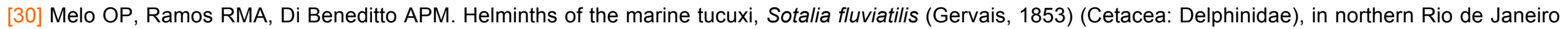
State, Brazil. Braz. Arch. Biol. Technol. 2006; 49: 145-148.

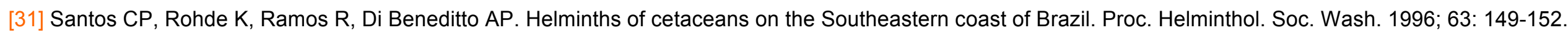

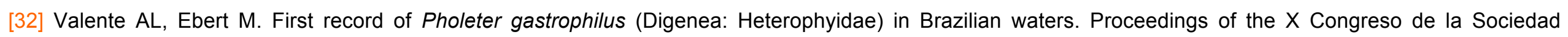
Latinoamericana de Especialistas en Mamíferos Acuáticos (SOLAMAC), Cartagena, Colombia, 1-5 December; 2014.

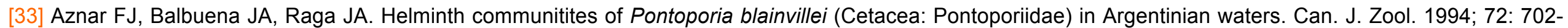
706.

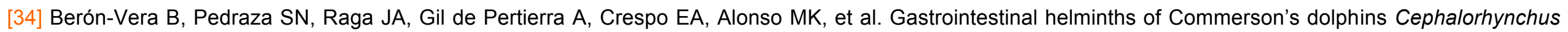
commersonii from central Patagonia and Tierra del Fuego. Dis. Aquat. Org. 2001; 47: 201-208. 


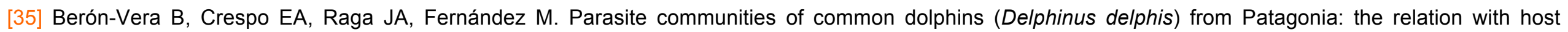
distribution and diet and comparison with sympatric hosts. J. Parasitol. 2007; 93: 1056-1060.

[36] Berón-Vera B, Crespo EA, Raga JA. Parasites in stranded cetaceans of Patagonia. J. Parasitol. 2008; 94: $946-948$.

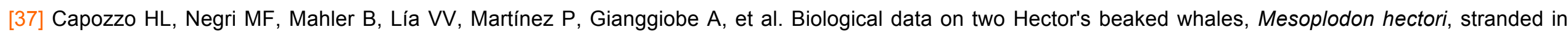
Buenos Aires Province, Argentina. LAJAM. 2005; 4: 113-128.

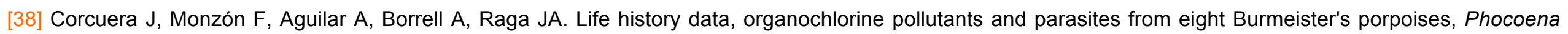
spinipinnis, caught in Northern Argentine waters. Rep. Int. Whal. Commn. 1995; 16: 365-372.

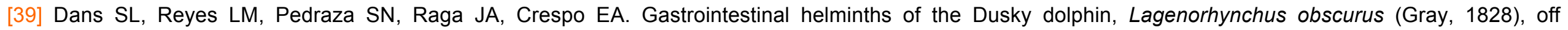
Patagonia, in the Southwestern Atlantic. Mar. Mamm. Sci. 1999; 15: 649-660.

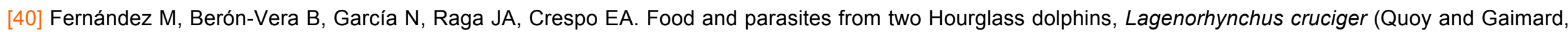
1824), from Patagonian waters. Mar. Mamm. Sci. 2003; 19: 832-836.

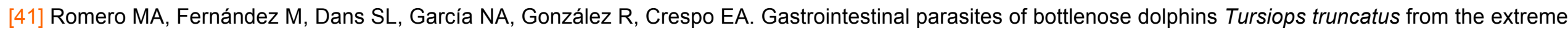
southwestern Atlantic, with notes on diet composition. Dis. Aquat. Org. 2014; 108: 61-70.

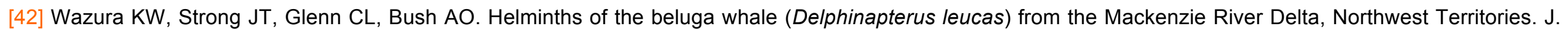
Wildl. Dis. 1986; 22: 440-442.

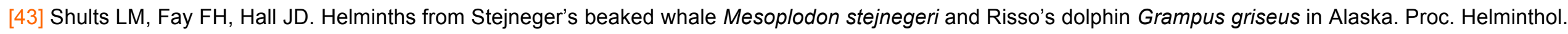
Soc. Wash. 1982; 49: 146-147.

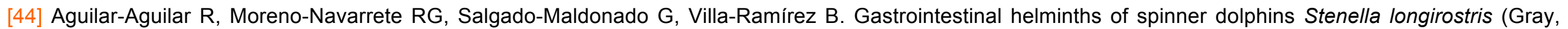
1828) (Cetacea: Delphinidae) stranded in La Paz Bay, Baja California Sur, Mexico. Comp. Parasitol. 2001; 68: $272-274$.

[45] Dailey MD, Stroud R. Parasites and associated pathology observed in cetaceans stranded along the Oregon coast. J. Wildl. Dis. 1978 ; $14: 503-511$.

[46] Dailey MD. Distribution of helminths in the Dall porpoise (Phocoenoides dalli True). J. Parasitol. $1971 ; 57: 1348$. 
[47] Dailey MD. Baseline data on parasites from marine mammals in Southern California. In Marine mammals and seabird survey of the Southern California Bight area. Vol. III. Principal investigator's reports. Book 1. Pinnipedia, Cetacea and Parasitology. Santa Cruz: University of California; 1978.

[48] Johnston DG, Ridgway SH. Parasitism in some marine mammals. J. Am. Vet. Med. Assoc. 1969; 155: 1064-1072.

[49] Kuramochi T, Kikuchi T, Okamura H, Tatsukawa T, Doi H, Nakamura K, et al. Parasitic helminth and epizoit fauna of finless porpoise in the Inland Sea of Japan and the Western North Pacific with a preliminary note on faunal difference by host's local population. Mem. Natl. Sci. Mus. (Tokyo). 2000; 33: 83-95.

[50] Miyazaki N, Fujise Y, Iwata K. Biological analysis of a mass stranding of melon-headed whales (Peponocephala electra) at Aoshima, Japan. Mem. Natl. Sci. Mus. (Tokyo). 1998; 24: 31-60.

[51] Parsons ECM, Overstreet RM, Jefferson TA. Parasites from Indo-Pacific hump-backed dolphins (Sousa chinensis) and finless porpoises (Neophocaena phocaenoides) stranded in Hong Kong. Vet. Rec. 2001; 23: 776-780.

[52] Tajima Y, Maeda K, Yamada TK. Pathological findings and probable causes of the death of Stejneger's beaked whales (Mesoplodon stejnegeri) stranded in Japan from 1999 and 2011. J. Vet. Med. 2015; 77: 45-51.

[53] Oliveira JB, Morales JA, González-Barrientos RC, Hernández-Gamboa J, Hernández-Mora G. Parasites of cetaceans stranded on the Pacific coast of Costa Rica. Vet. Parasitol. 2011; 182: 319-328.

[54] Dailey MD, Perrin WF. Helminth parasites of porpoises of the genus Stenella in the Eastern Tropical Pacific, with descriptions of two new species: Mastigonema stenellae gen. et. sp. n. (Nematoda: Spiruroidea) and Zalophotrema pacificum sp. n. (Trematoda: Digenea). Fish. Bull. 1973; 71: 455-471.

[55] Reyes JC, Van Waerebeek K. Aspects of the biology of Burmeister's porpoise from Peru. Rep. Int. Whal. Commn. 1993; $16: 349-364$.

[56] Tantalean M, Cabrera R. Algunos helmintos de la marsopa espinosa, Phocoena spinipinnis de la Reserva Nacional de Paracas, Perú. Parasitol. al día 1999; 23: 56-57.

[57] Van Waerebeek K, Reyes JC, Alfaro J. Helminth parasites and phoronts of dusky dolphins Lagenorhynchus obscurus (Gray 1828) from Peru. Aquat. Mamm. 1993; 19: 159-169. 
[58] Torres P, Oporto JA, Brieva LM, Escare L. Gastrointestinal helminths of the cetaceans Phocoena spinipinnis (Burmeister, 1865) and Cephalorhynchus eutropia (Gray, 1846) from the Southern coast of Chile. J. Wildl. Dis. 1992; 28: 313-315.

[59] Lane EP, de Wet M, Thompson P, Siebert U, Wohlsein P, Plön S. A systematic health assessment of Indian Ocean bottlenose (Tursiops aduncus) and IndoPacific humpback (Sousa plumbea). Plos ONE. 2014; 9: e107038.

[60] McKenzie J, Blair D. Parasites from Hector's dolphin (Cephalorhynchus hectori). New Zeal. J. Zool. 1983; 10: 126-127.

[61] Cornaglia E, Rebora L, Gili C, Di Guardo G. Histopathological and immunohistochemical studies on cetaceans found stranded on the coast of Italy between 1990 and 1997. J. Vet. Med. A 2000; 47: 129-142.

[62] Fernández M, Agustí C, Aznar FJ, Raga JA. Gastrointestinal helminths of Risso's dolphin Grampus griseus from the Western Mediterranean. Dis. Aquat. Org. 2003a; 55: 73-76.

[63] Fernández M, Aznar FJ, Montero FE, Georgiev BB, Raga JA. Gastrointestinal helminths of Cuvier's beaked whales, Ziphius cavirostris, from the western Mediterranean. J. Parasitol. 2004; 90: 418-420.

[64] Manfredi MT, Dini W, Ganduglia S, Podesta M, Repetto G. Parasitological findings in striped dolphins Stenella coeruleoalba. Proceedings of the 6th Annual Conference of the European Cetacean Society, San Remo, Italy 20-22 February; 1992. pp. 218-219.

[65] Raga JA, Carbonell E. New data about parasites on Stenella coeruleoalba (Meyen, 1833) (Cetacea: Delphinidae) in the western Mediterranean Sea. Invest. Cetacea. 1985; 17: 207-213.

[66] Aytemiz I, Dede A, Danyer E, Tonay A. Morphological identification of parasites found in the stomach contents of bycaught striped dolphins (Stenella coeruleoalba) from Turkish Eastern Mediterranean Sea coast. J. Black Sea/Mediterranean Environment. 2012; 18: 238-245.

[67] Delyamure SL. Towards the study of the helminth fauna of the dolphin, Tursiops tursio. J Fish Res Board Can 1959; 134: 1-5.

[68] Kleinertz S, Hermosilla C, Ziltener A, Kreicker S, Hirzmann J, Abdel-Ghaffar F, et al. Gastrointestinal parasites of free-living Indo-Pacific bottlenose dolphins (Tursiops aduncus) in the Northern Red Sea, Egypt. Parasitol. Res. 2014; 113: 1405-1415. 